\title{
PENINGKATAN HASIL BELAJAR BAHASA INDONESIA MENGGUNAKAN METODE INKUIRI DENGAN MEDIA KONKRET PADA PESERTA DIDIK PALANGKARAYA
}

\author{
Oleh : Helpy Patriana Arifien* \& Suniati, M.Pd
}

\begin{abstract}
ABSTRAK
Penelitian ini bertujuan untuk: (1) untuk mendeskripsikan aktivitas belajar peserta didik dalam pembelaajran Bahasa Indonesia menggunakan metode inkuiri dengan media konkret pada pesera didik kelas II-A SDN 5 Panarung Palangkaraya tahun pelajaran 2016/2017. (2) untuk meningkatan hasil belajar Bahasa Indonesia menggunakan metode inkuiri dengan media konkret pada pesera didik kelas II-A SDN 5 Panarung Palangkaraya tahun pelajaran 2016/2017. Jenis penelitian adalah Penelitian Tindakan Kelas. Subjek penelitian adalah siswa kelas II-A SDN 5 Palangkaraya yang berjumlah 29 peserta didik terdiri dari 19 orang peserta didik laki-laki dan 10 orang peserta didik perempuan. Teknik pengumpulan data dalam penelitian ini menggunakan tes dan observasi. Analisis data menggunakan analisis data kualitatif dan kuantitatif. Hasil penelitian menunjukkan bahwa: (1) Aktivitas belajar Bahasa Indonesia peserta didik kelas II-A di SDN-5 Panarung Palangkaraya. Skor rata-rata yang diperoleh peserta didik pada siklus I adalah 3,56 dan skor rata-rata pada siklus II adalah 3,57 dengan kriteria sangat baik. (2)Terdapat peningkatan hasil belajar Bahasa Indonesia peserta didik kelas II-A di SDN-5 Panarung Palangkaraya dengan penerapan metode inkuiri dengan media konkret. Tes awal nilai rata-rata peserta didik yang diperoleh adalah 69,96 dan ketuntasan klasikal $44,82 \%$. Nilai rata-rata setelah penerapan metode inkuiri dengan media konkret meningkat pada siklus I yaitu 79,96 dan ketuntasan klasikalnya $82,75 \%$ serta lebih tingkatkan lagi pada siklus II dengan nilai ratarata 87,86 dan ketuntasan klasikal $100 \%$.
\end{abstract}

\section{Kata Kunci: Hasil Belajar Bahasa Indonesia, Metode Inkuiri, Media Konkret}

\begin{abstract}
This study aims to describe the learning activities of students in learning Indonesian Language using inquiry methods with concrete media on class II-A students at Panarung Palangkaraya 5 Elementary School in the 2016/2017 academic year, and improve learning outcomes in Indonesian using inquiry methods with real press on the second grade students of SDN 5 Panarung Palangkaraya 2016/2017 academic year. This type of research is Class Action
\end{abstract}


Research. The research subjects were class II-A students at SDN 5 Palangkaraya, totalling 29 students consisting of 19 male students and ten female students. Data collection techniques in this study used tests and observations. Data analysis uses qualitative and quantitative data analysis. The results showed that Indonesian language learning activities of class II-A students at Panarung SDN-5 Palangkaraya. The average score obtained by students in the first cycle is 3.56 and the average rating in the second cycle is 3.57 with perfect criteria. There is an increase in Indonesian language learning outcomes of class II-A students at Panarung Palangkaraya SDN-5 with the application of inquiry methods with real media. The initial test of the average value of students obtained was 69.96, and classical completeness was $44.82 \%$. The average cost after the application of the inquiry method with real media increased in the first cycle of 79.96, and artistic integrity was $82.75 \%$, and more increased in the second cycle with an average value of 87.86 and $100 \%$ classical completeness.

Keywords: Results of Learning Indonesian, Inquiry Methods, Concrete Media

\section{PENDAHULUAN}

Bahasa merupakan hal yang sangat penting dalam komunikasi. Dua atau lebih manusia yang berkomunikasi menggunakan bahasa yang sama dapat membuat mereka memahami maksud dari penyampai pesan. Pesan yang disampaikan tersebut dapat berupa pengungkapan gagasan ataupun perasaan baik secara lisan maupun tertulis. Bahasa yang digunakan oleh Warga Negara Indonesia adalah Bahasa Indonesia. Hal ini sesuai dengan sumpah pemuda yang menyatakan bahwa bahasa persatuan adalah Bahasa Indonesia. Sekolah-sekolah menggunakan Bahasa Indonesia sebagai salah satu mata pelajaran yang dianggap penting. Terbukti dalam pelaksanaan Ujian Nasional, mata pelajaran Bahasa Indonesia merupakan salah satu mata pelajaran yang diujikan.

Salah satu pengajaran bahasa Indonesia secara umum adalah agar siswa memiliki disiplin dalam berpikir dan berbahasa. Kebiasaan seseorang berpikir logis akan sangat membantu dalam pengajaran bahasa. Dalam pengajaran bahasa dikenal adanya empat keterampilan berbahasa yang perlu dicapai siswa, yaitu: keterampilan mendengarkan, keterampilan berbicara, keterampilan membaca, dan keterampilan menulis. 
Keempat keterampilan tersebut saling berhubungan dan tidak boleh dipisah-pisahkan. Keterampilan berbicara dan keterampilan menulis merupakan keterampilan produktif, artinya siswa diharapkan mempunyai keterampilan dan kemampuan mengungkapkan gagasan menggunakan bahasa lisan maupun bahasa tulisan. Menurut Sanjaya (2012:203) Tujuan pembelajaran dapat menentukan pengalaman belajar yang harus dilakukan peserta didik. Hal ini sering dilupakan guru. Guru yang senang berceramah, hampir setiap tujuan menggunakan strategi penyampaian, peserta didik dipaksa untuk mendengarkan penjelasan guru. Hal ini tentu saja keliru. Apabila kita menginginkan peserta didik terampil, peserta didik harus berpengalaman belajar berpraktik secara langsung.

Berdasar hasil observasi di SDN 5 Panarung Palangka Raya kelas II-A yang di lakukan pada tanggal 8 Agustus 2016, ditemukan dalam setiap pembelajaran guru di kelas kurang memanfaatkan media pembelajaran, guru masih berpusat pada media buku pegangan guru dan mencatat dipapan tulis. Peserta didik terlihat bosan dan tidak memperhatikan penjelasan dari guru. Pembelajaran menjadi tidak menyenangkan bagi peserta didik dan tujuan pendidikan menjadi tidak tercapai secara optimal. Media yang digunakan dalam proses pembelajaran berupa papan tulis dan buku pegangan guru sebagai latihan untuk menulis. Hal ini ditunjukkan dengan nilai yang masih dibawah KKM yang telah ditentukan pada pelajaran Bahasa Indonesia yaitu 7. Dari 29 peserta didik ada 19 peserta didik yang tidak mencapai KKM.Berdasarkan permasalahan tersebut, untuk meningkatkan hasil belajar Bahasa Indonesia secara tertulis dengan menggunakan metode inkuiri adalah strategi pembelajaran yang tepat.

Hamiyah dan Jauhar (2014:185) berpendapat "Strategi inkuiri menekankan aktivitas siswa secara optimal untuk mencari dan menemukan, peserta didik tidak hanya berperan untuk menemukan sendiri sesuatu yang dipertanyakan, sehingga diharapkan dapat menumbuhkan sikap percaya diri (self-belief). Penempatan guru bukan sebagai sumber belajar, akan tetapi 
sebagai fasilisator dan motivator belajar, mengembangkan kemampuan intelektual sebagai bagian dari proses mental, peserta didik tidak hanya dituntut untuk menguasai pelajaran, akan tetapi bagaimana mereka dapat menggunakan potensi dalam dirinya".

Sanjaya, (Hamiyah \& Jauhar 2014:186) menyatakan bahwa pembelajaran inkuiri mengikuti langkah-langkah sebagai berikut:

1) Orientasi

Pada tahap ini guru menjelaskan langkah untuk membina suasana atau iklim pembelajaran yang kondusif. Hal yang dilakukan dalam tahap ini adalah:

a. Menjelaskan topik, tujuan, dan hasil belajar yang diharapkan dapat dicapai oleh peserta didik.

b. Menjelaskan pokok-pokok kegiatan yang harus dilakukan oleh peserta didik untuk mencapai tujuan. Pada tahap ini, dijelaskan langkahlangkah inkuiri serta tujuan setiap langkah, mulai dari langkah merumuskan masalah sampai dengan merumuskan kesimpulan.

c. Menjelaskan pentingnya topik dan kegiatan belajar. Hal ini dilakukan untuk memberikan motivasi belajar peserta didik.

2) Merumuskan Masalah.

Merumuskan masalah merupakan langkah untuk membawa peserta didik pada suatu persoalan yang mengandung teka-teki. Persoalan yang disajikan adalah persoalan yang menantang peserta didik untuk memecahkan teka-teki itu. Teka-teki dalam rumusan masalah tentu ada jawabannya, dan peserta didik didorong untuk mencari jawaban yang tepat. Proses mencari jawaban itulah yang sangat penting dalam pembelajaran inkuiri. Oleh karena itu, melalui proses tersebut, peserta didik akan memperoleh pengalaman yang sangat berharga sebagai upaya untuk mengembangkan mental melalui proses berpikir.

3) Merumuskan Hipotesis.

Hipotesis adalah jawaban sementara dari suatu permasalahan yang dikaji. Sebagai jawaban sementara, hipotesis perlu diuji 
kebenarannya. Salah satu cara yang dapat dilakukan guru untuk mengembangkan kemampuan menebak (berhipotesis) pada setiap anak adalah dengan mengajukan berbagai pertanyaan yang dapat mendorong peserta didik untuk merumuskan jawaban sementara atau berbagai perkiraan atas kemungkinan jawaban dari suatu permasalan yang dikaji.

4) Mengumpulkan Data

Mengumpulkan data adalah aktivitas untuk menjaring informasi yang dibutuhkan dalam menguji hipotesis yang diajukan. Dalam pembelajaran inkuiri, mengumpulkan data merupakan proses mental yang sangat penting dalam pengembangan intelektual. Proses pengumpulan data bukan hanya memerlukan motivasi yang kuat dalam belajar, akan tetapi juga membutuhkan ketekunan dan kemampuan dalam menggunakan potensi berpikirnya.

5) Menguji Hipotesis.

Menguji hipotesis adalah
menentukan jawaban yang
dianggap diterima sesuai dengan
data atau informasi yang diperoleh
berdasarkan pengumpulan data.

Menguji hipotesis juga berarti mengembangkan kemampuan berpikir rasional. Artinya, kebenaran jawaban yang diberikan bukan hanya berdasarkan argumentasi, akan tetapi harus didukung oleh data yang ditemukan dan dapat dipertanggungjawabkan.

6) Merumuskan Kesimpulan

Merumuskan kesimpulan adalah proses mendekripsikan temuan yang diperoleh berdasarkan hasil pengujian hipotesis. Untuk mencapai kesimpulan yang akurat guru sebaiknya mampu menunjukkan kepada peserta didik tentang mana data yang relevan.

Abdul Majid (2014: 227) keunggulan strategi pembelajaran inkuiri merupakan strategi pembelajaran yang banyak dianjurkan oleh karena strategi ini memiliki beberapa keunggulan, diantaranya:

1) Strategi ini merupakan strategi pembelajaran yang menekankan kepada pengembangan aspek kognitif, afektif, dan psikomotor secara seimbang, sehingga pembelajaran melalui strategi ini dianggap lebih bermakna. 
2) Strategi ini dapat memberikan ruang kepada peserta didik untuk belajar sesuai dengan gaya belajar mereka.

3) Strategi ini merupakan strategi yang dianggap sesuai dengan perkembangan psikologi belajar modern yang menganggap belajar adalah proses perubahan tingkah laku berkat adanya pengalaman.Keuntungan lain adalah strategi pembelajaran ini dapat melayani kebutuhan peserta didik yang memiliki kemampuan diatas rata-rata. Artinya, peserta didik yang memiliki kemampuan belajar bagus tidak akan terhambat oleh peserta didik yang lemah dalam belajar.

Wina Sanjaya (2006: 208), di samping memiliki keunggulan, strategi ini juga memiliki kelemahan, diantaranya:

1) sehingga sering guru sulit menyesuaikannya dengan waktu yang telah ditentukan.

Selama kriteria keberhasilan belajar ditentukan oleh kemampuan peserta didik menguasai materi pelajaran, maka strategi ini akan sulit diimplementasikan oleh setiap guru.mpunyai kelemahan, di antaranya:

2) Jika strategi ini merupakan strategi pembelajaran, maka akan sulit mengontrol kegiatan dan keberhasilan peserta didik.

3) Strategi ini sulit dalam merencanakan pembelajaran oleh karena terbentur dengan kebiasaan peserta didik dalam belajar.

4) Kadang-kadang dalam mengimplementasikannya, memerlukan waktu yang panjang

\section{METODE PENELITIAN}

Penelitian ini menggunakan penelitian tindakan kelas (PTK). Menurut Kemmis dan Mc Taggart (Sukardi 2012:3) “penelitian tindakan adalah cara suatu kelompok atau seseorang dalam mengorganisasi sebuah kondisi di mana mereka dapat diakses oleh orang lain. Sedangkan kelas adalah tempat para guru melakukan penelitian, dengan dimungkinkan mereka tetap bekerja sebagai guru di tempat kerjanya". 
Dalam penelitian, kehadiran peneliti mutlak diperlukan karena kehadiran peneliti sangat diperlukan dalam setiap kegiatam di tempat penelitian. Peneliti berperan sebagai perencana, pelaksana tindakan, pengamat, reflektor dan sebagai pelapor hasil penelitian.

Subjek yang menjadi penelitian adalah peserta didik kelas II SDN 5 Panarung Palangka Raya Tahun Ajaran 2016/2017 yang berjumlah 29 orang terdiri dari 19 laki-laki dan 10 perempuan.

Teknik pengumpul data yang digunakan pada penelitian ini yaitu observasi dan tes.

Menurut Kunandar (2012: 143), menjelaskan observasi adalah "kegiatan pengamatan (pengambilan data) untuk memotret seberapa jauh efek tindakan telah mencapai sasaran".

Menurut Arikunto (Sangadji dan Sopiah, 2010: 150), bahwa tes adalah "serentetan pertanyaan dan latihan serta alat lain yang digunakan untuk mengukur keterampilan, pengetahuan intelegensi, kemampuan, atau bakat yang dimiliki oleh individu atau kelompok".
Data yang dikumpulkan dari setiap kegiatan yang akan dilaksanakan dalam siklus PTK dianalisis secara deskriptif dengan menggunakan teknik presentase untuk melihat kecenderungan yang terjadi dalam pembelajaran. data yang diperoleh melalui instrument sebelumnya diolah lebih dulu menjadi dua jenis yaitu data kualitatif dan kuantitatif.

Data kualitatif digunakan untuk memberi keterangan tentang proses pembelajaran. Sedangkan data kuantitatif untuk mengetahui jumlah peningkatan hasil belajar setelah proses pembelajaran menggunakan metode inkuiri menggunakan media konkret.

\section{HASIL DAN PEMBAHASAN}

Pelaksanaan tindakan pada pembelajaran Bahasa Indonesia dengan menggunakan metode inkuiri dengan media konkret pada materi menaympaikan ciri-ciri tumbuhan yang dilaksanakan di SDN-5 Panarung Palangkaraya diperoleh dari hasil pengamatan lembar observasi guru dan peserta didik yaitu dari dua pengamat menunjukkan bahwa untuk aktivitas 
guru dengan nilai rata - rata 3,54 dengan kriteria baik dan peserta didik dengan nilai rata - rata 3,56 dengan kriteria sangat baik.

Berdasarkan analisis data yang dilakukan terhadap aktivitas belajar peserta didik maka dapat diperoleh data hasil aktivitas belajar peserta didik pada siklus I yaitu, aktivitas belajar peserta didik memperoleh skor rata-rata3,56 dengan kriteria sangat baik. Aktivitas belajar peserta didik pada siklus II memperoleh ratarata 3,57 dengan kriteria sangat baik Hasil belajar peserta didik pada saat tes awal memperoleh nilai rata-rata 69,96 (dibawah $\mathrm{KKM} \geq 70$ ) dengan ketuntasan klasikal 44,82\%. Pada siklus I peserta didik memperoleh nilai rata-rata 79,96 dengan ketuntasan klasikal 82,75\%. Dan pada siklus II peserta didik memperoleh rata-rata 87,65 dengan ketuntasan klasikal $100 \%$.

Gambar 1. Grafik hasil belajar peserta didik dalam melaksanakan pembelajaran menggunakan metode inkuiri dengan menggunakan media konkret

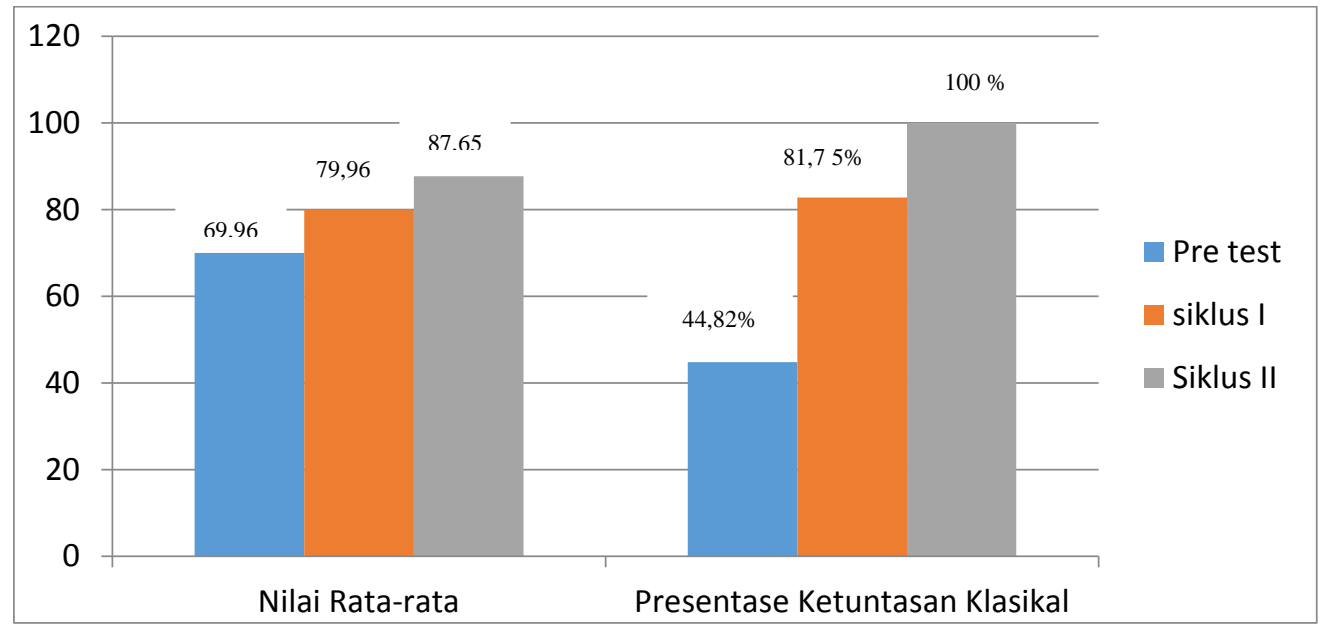

\section{KESIMPULAN}

1. Aktivitas belajar peserta didik kelas II-A di SDN-5 Panarung Palangkaraya sangat baik pada saat pembelajaran Bahasa Indonesia dengan penerapan metode inkuiri dengan media konkret. Skor rata-rata yang diperoleh peserta didik pada siklus I adalah 3,56 dan skor rata-rata pada siklus II adalah 3,57 dengan kriteria sangat baik. Peserta didik aktif dalam mengikuti proses pembelajaran, 
hasil yang diperoleh mencapai indikator ketercapaian yang telah ditetapkan, sehingga dikatakan berhasil.

2. Ada peningkatan hasil belajar Bahasa Indonesia peserta didik kelas II-A di SDN-5 Panarung Palangkaraya dengan penerapan metode inkuiri dengan media konkret. Tes awal nilai rata-rata peserta didik yang diperoleh adalah 69,96 dan ketuntasan klasikal $44,82 \%$. Nilai rata-rata setelah penerapan metode inkuiri dengan media konkret meningkat pada siklus I yaitu 79,96 dan ketuntasan klasikalnya $82,75 \%$ serta lebih tingkatkan lagi pada siklus II dengan nilai rata-rata 87,65 dan ketuntasan klasikal $100 \%$. Penerapan metode inkuiri dengan media konkret ini diterapkan pada pembelajaran Bahasa Indonesia untuk mengembangkan kemampuan peserta didik dalam mengamati dan melatih menulis dengan baik secara individu maupun kelompok.

\section{DAFTAR PUSTAKA}

Arikunto, Suharsimi. 2010. Penelitian Tindakan Kelas. Jakarta: PT. Bumi Aksara

Hamiyah \& Jauhar, 2014 ; Strategi Belajar-Mengajar Di Kelas; Jakarta; Prestasi Pustaka Publisher

Kunandar. 2012. Penelitian Tindakan Kelas. Jakarta: RajaGrafindo Persada

Sangadji, Etta Mamang. Sopiah. 2010. Metodologi Penelitian Pendekatan Praktis dalam Penelitian. Yogyakarta: C.V ANDI OFFSET.

Sukardi, M. 2011. Evaluasi Pendidikan Prinsip dan Operasionalnya. Jakarta: PT Bumi Aksara.

Sanjaya, Wina. 2006. Strategi Pembelajaran Berorientasi Standar Proses Pendidikan. Jakarta. Kencana Prenada Media Group 